$1-1-1890$

\title{
Meteorological report for August ; Reports of correspondents upon meteorology and crops for August
}

John A. Myers

Follow this and additional works at: https://researchrepository.wvu.edu/ wv_agricultural_and_forestry_experiment_station_bulletins

\section{Digital Commons Citation}

Myers, John A., "Meteorological report for August ; Reports of correspondents upon meteorology and crops for August" (1890). West Virginia Agricultural and Forestry Experiment Station Bulletins. 10.

https://researchrepository.wvu.edu/wv_agricultural_and_forestry_experiment_station_bulletins/10 @ WVU. It has been accepted for inclusion in West Virginia Agricultural and Forestry Experiment Station Bulletins by an authorized administrator of The Research Repository @ WVU. For more information, please contact ian.harmon@mail.wvu.edu. 
West Virginia University Libraries

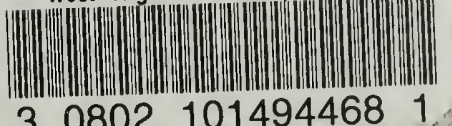

308021014944681 . 



\section{BULLETIN NO. 10.}

OF THE

\section{WEST VIRGINIA}

\section{Agricultural dixperiment Station.}

AUGUST, 1890.

I. Meteorological Report for August.

II. Reports of Correspondents upon Metecrology and Cropz for August.

By John A. Myers, Director.

The Direcior does not hold himself responsible for the opinions of Correspondents.

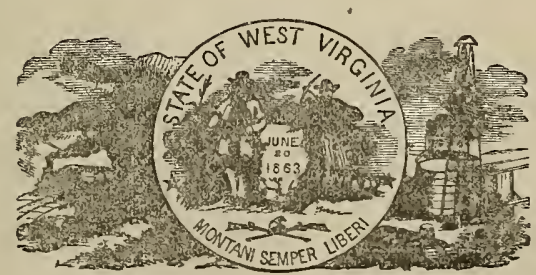

CHARLESTON :

Mloses W. Doñally, Public Painter.

1590. 
BOARD OF REGENTS OF THE WEST VIRGINIA UNIVERSITY

District.

Name of Regent.

1. J. B. SOMMERVILLE,

2. CLARENCE L. SMITH,

3. PEREGRIN HAYES,

4. D. D. JOHNSON,

5. JOHN G. SCHILLING,

6. EDWARD A. BENNETT,

7. WIRT A. FRENCH,

8. M. J. KESTER,

9. D. C. GALLAHER,

10. THOMAS J. FARNSWORTH,

11. JOSEPH MORELAND,

12. JOHN A. ROBINSON,

13. DR. W. W. BROWN,
P. O. Address.

Wheeling.

Fairmont.

Glenville.

Long Reach.

Spencer.

Huntington.

Princeton.

Union.

Charleston.

Buckhannon.

Morgantown.

Patterson's Depot.

Kabletown.

MEMBERS OF THE STATION COMMITTEE.

JOHN A. ROBINSON, JOSEPH MORELAND,
JOHN G. SCHILLING,

THOMAS J. FARNSWORTH,

DR. W. W. BROWN.

President of the University.

TREASURER.

E. M. TURNER, LL. D.,

JOHN I. HARVEY.

STATION STAFF.

JOHN A. MYERS, Pr. D., C. F. MILLSPAUGE, M. D.,

D. D. JOHNSON, A. M., H. R. BALDWIN, Jr., A. D. HOPIKINS, SUSIE V. MAYERS,
Director.

- Botanist and Microscopist.

Agriculturist. - Chemist. Etomologist. Stenographer and Book-keeper. 
REPORT OF W. C. KISEN-FRANKLIN, PENDLETON CO., W. VA.

\section{For Month of August, 1890.}

Weather warm and dry. Very little rain. Frnst on the 25th. No damage done. Corn not more than half a crop. Wheat half crop Oats medium. No barlev. Buckwheat not harvested, but will be short. Grass good. Fruit a failure. Cattle in fine conditior, but no market for them. Horses, gnod condition, pricss low. Sheep, condition and prices good. Swine scarce. Prultry not doing well. No new entexprises being developed. The principal farming industries are raising cattle, theep and horses. No.hing else can be made profitable without a railroad running through the county, which we have not.

REPORT OF A. W. WESTFALL-AUBURN, RITCHE CO., W. VA.

For Month of August, 1890.

Weather changeable. Plenty of rain for vegetation. Corn about three-quarter crop. Wheat one half an average crop. Fruit almost an entire failure. Stock generally in good condition. Market good, especially sheep and poultry, no disease attacking them. No new enterprises being developed, but there are a number that could be profitably carried on in this county. Stock and grain raising are the principal farming industries. Everything except grains and fruits in fair condition.

REPORT OF J. W. CARTER-PLEASANT DALE, HAMPSHIRE CO., W. VA.

\section{For the Month of August, 1890.}

Temperature above the average. Mostly dry.

Corn promises about one-half crop. Buckwheat the same. Fruit a failure. Should frost be late buck wheat may make threefourths crop. Wheat is boing threshed and vields about as reported for last month. Condition of live stoc'z go :d. Market for cattle flat. Large good horses bring g sod prices. Sheep high and scarce. Swine and poultry command good prices. No new enterprises being develeped.

REPORT OF W. A. MIORGAN-SHEPHERDSTOWN, JEFFERSON CO., W. VA.

\section{For Month of August, 1890.}

Unusually wet, with frequent heavy washing rains. Much cold, cloudy weather. Corn growing finely and promising a heavy yield. Very little in the way of fruit of any description. Wheat on low ground inferior in quality and yield to that growa on high or rolling land. Live stock healthy and in good order, there be- 
ing fine grass and pasture. Market fair to good. Stock, cattle and sheep in good demand at fair prices. Morgan Grove Agricultural and Mechanical Association growing rapidly in importance. The principal farming industries are wheat, corn, oats, potatoes and hay. Fruit marketing and dairying more profitable. Farmers much encouraged at the prospect of better prices. But fear the passage of the McKinley tariff bill.

REPORT OF R. A. ALENANDER-CHARLESTOWN, JEFFERSON CO., W. VA.

For the Month of August, 1890.

Rather dry first of month, but have been having fine rains lately. Corn very fine. Wheat where it was not struck by hail is turning out very well and the quality is good. Live stock in fine condition and market good. The new enterprise is to boom Charlestown and Shenandoah Junctions. The principal farming industries are wheat, corn, cattle and sheep. Since the effort to boom this section, iron has been found in large quantities and good quality.

REPORT OF S. A. HOUSTON-PICKAWAY, MUNROE CO., W. VA:

For Month of August, 1890.

Weathery very very,dry. Corn one-half crop. Oats one-third crop. Hay good. Pasture burnt up in many sections of the county. Rather seasonable in others. Very little fruit of any kind. Condition of live stock good up to this time. No disease among them. Market about as last year at this time. Our creamery has been established. Stock raising is the principal farming industry. All farmers have come to the conclusion that there will have to be a great change of some character before farming can be made to pay.

REPORT OF M. L. BRYTE-BRUCET ON MILLS, PRESTON CC., W. VA.

For the Month of August, 1890 .

Much rain during the month. Streams full; roads washed. Never knew a greater rainfall during August. -Corn good generally, large acreage, best prospects for several yearg. Wheat not a full crop, but better than farmers thought it would be--yield better. Appearances indicate an enormous crop of buckwheat. Oats almost a failure. Grass good. Hay plenty. Condition, of live stock very good generally, no diseases. Market for cattle medium; for sheep good. But few sheep unsold in the county. No new enterprises being developed, but the creamery at 'Terra Alta which is about completed. The principal farming industries are stock of all kinds. Wheat, corn, oate, grass and buckwheat profi- 
tably raised. Creameries could be profitably introduced. 'T'he continued wet weather injured the wheat and oats. Wheat is vieldiug much better than farmers anticipated. Pasture excellent.

REPORT OF GEORGE T. IGBERT--RAVEN'S EYE, FAYETTE CO., W. VA.

F.or the Month of August, 1890.

Frequent showers of rain. Frost on 2 th instant. Buckwheat promising. Corn fair. Fall pasture much improved by late rains. Fruit crop an entire failure. Condition of live stock good. No demand except for sheen, which are scarce and high. No new enterprises being developed. Stock raising is the principal farming industry.

KEPORT OF ADAM FISHER-MOORMEIELD, HARDY CO., W. VA.

For the Month of August.

A little rain has fallen in the last two weeks. The corn crop will average twenty-five bushels per acre in the valleys, but on the hills will be very light. Oats less than half a crop. Wheat about one-third. Grass crop unprecedented. Live stock in good condition. Sheep in demand. Hogs muusually dull. Some inquiry for cattle. Some strangles among horses. No new enterprises being developed. The principal farming industries are grain and stock raising. Fruit an entire frailure. Potatoes selling at 75 cents per bushel.

REPORT OF J. P. HALE-CHARLEGTON, KANAWHA CO., W. VA.

For Month of August, 1890.

Usual summer temperature. More than average rain fall. Corn crop will be less than usual on account of late planting and too much wet weather for working. Wheat crop three-quarters crop. Oats about 90 per cent. Barley and buckwheat none raised. Grass above average. Fruit nearly a tailure. Live stock condition very good. Average market. No new enterprise being developed. It is believed that Alfalfa or Mexican clover would do well here, but it has not been tried. 


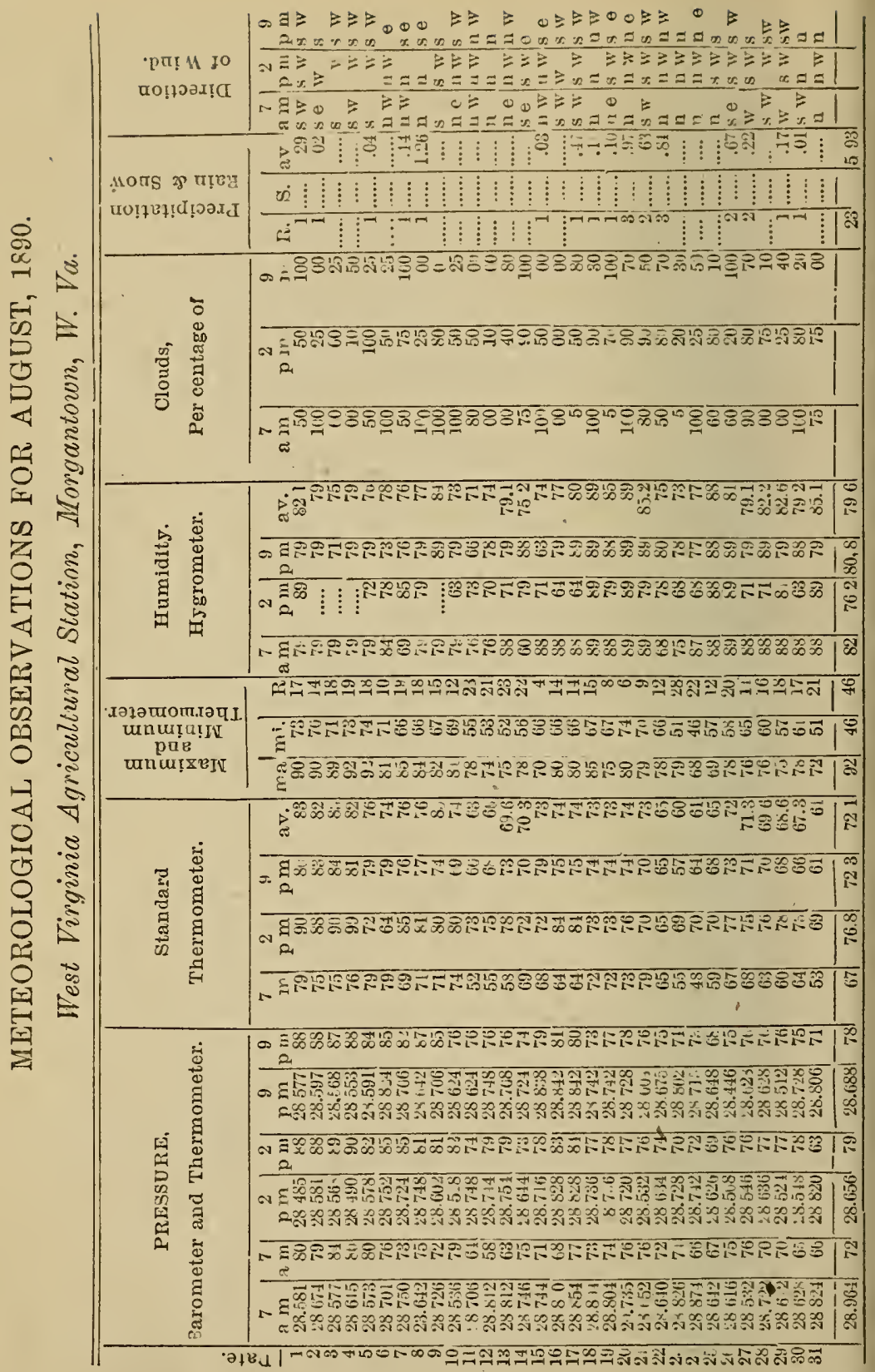




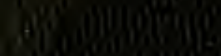

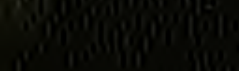

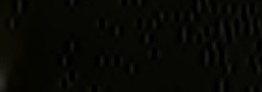

II

(1)

1

(11) 